\title{
Alternative Energy Source in a Developing Country: Biodiesel Option in Nigeria.
}

\section{${ }^{* 1}$ UZOEKWE, A. STEPHEN; ${ }^{2}$ OMOROGBE, STANLEY; HAMILTON- AMACHREE, AKENS}

\author{
1Department of Chemical Sciences, Faculty of Science, Federal University, Otuoke \\ 2 Product Development Division, Rubber Research Institute of Nigeria, Iyanomo. \\ *Corresponding Author: Uzoekwe A. Stephen. Email : uzoekwe steve@yahoo.com
}

\begin{abstract}
The depleting reserves of petroleum and attendant environmental issues have led to the search for more eco - friendly and renewable fuels. Biodiesel obtained from various renewable sources have been recognized as one of the alternative fuels due to its biodegradability, high cetane number, no sulphur emissions and low volatility. In this paper, biodiesel was obtained from waste frying oil (WFO) by esterification to reduce the free fatty acid (FFA) content (determined by standard titration methods) and then transesterified using base catalyzed transesterification method. The WFO had an FFA content of $11.3 \%$. The WFO was esterified hourly $(1,2,3,4)$ for reduction in \%FFA until about < 1\% FFA was achieved prior to transesterification. The esterified oil was transesterified in batches to establish optimum conditions for the reaction by varying; time, temperature, stirring speed and methanol to oil molar ratio respectively. The methyl ester yield from the efficient based catalyzed transesterification of WFO were found to be $50^{\circ} \mathrm{C}, 6: 1$ methanol-to-oil molar ratio, $1 \% \mathrm{w} / \mathrm{v}$ catalyst concentration and a reaction time duration of 40 minutes, $96 \%$ optimum yield and the result of the FTIR analysis confirms the formation of methyl ester having wavelength of absorption at $2959.475 \mathrm{~nm}, 2784.153 \mathrm{~nm}, 1747.191$ and 1469.005 respectively. The fuel properties of the methyl ester produced were compared with set ASTM standards and were found to be in line with the standards. (C) JASEM
\end{abstract}

http://dx.doi.org/10.4314/jasem/v19i3.7

KEYWORDS: Waste frying oil, co-solvent, Transesterification, Yield, FTIR analysis and Fuel Properties

\section{Introduction}

The economy of Nigeria today is solely dependent on the sale and use of petroleum based energy fuel with attendant environmental consequences. There is need for environmentally attractive alternative as an option in diversification of a mono-economy. Biodiesel is a fuel composed of monoalkylesters of long-chain fatty acids derived from renewable vegetable oil or animal fats (ASTM, 2008).

Biodiesel which readily mixes with petroleum diesel in any ratio, is made from renewable energy sources, can be burnt in modern engines with little or no modification. It ensures reduction in emission of $\mathrm{SO}_{2}$, soot, CO e.t.c. These have encouraged the use of biodiesel as alternative source of energy.

Vegetable oils or animal fats are principally composed of triacylglycerols consisting of long-chain fatty acids chemically bound to glycerol (1, 2, 3-propanetriol) backbone. Through transesterification reaction, triacylglycerol stepwise is converted into biodiesel: short chain monohydric alcohol initially react with triacylglycerol as alkoxide ion in presence of a catalyst at elevated temperature to form fatty acid alkyl esters (FAAE) and diacylglycerols (DAG), which react further with alcohol (alkoxide) to liberate another molecule of fatty acid alkyl ester (FAAE) and generate monoacylglycerols (MAG) and lastly monoacylglycerols undergoes alcoholysis to yield glycerol and fatty acid alkyl ester (FAAE), with the combined FAAE collectively known as biodiesel (Moser, 2009). The chemical composition of biodiesel is dependent upon the feedstock from which it was produced as vegetable oil and animal fats of differing origins have dissimilar fatty acid compositions (Gunstone and Harwood, 2007). The fatty acid ester composition of biodiesel is identical to that of the parent oil or fat from which it was produced. Vegetable oil production and biodiesel feedstock usage are intimately related (USDA, 2008).

Feedstock for biodiesel production varies with location according to climate and availability. Generally, the most abundant commodity oil or fats in a particular region are the most common feedstock. Thus, 
rapeseeds and sunflowers oils are principally used in Europe for biodiesel production, palm oil predominates in the tropical countries, and soyabean oil and animal fats are most common in USA (Demirbas, 2006).

Biodiesel is produced commercially using homogenous basic catalyst such as sodium (or potassium) hydroxide or methoxide because the transesterification reaction is generally faster, less expensive and more complete with these materials than with acid catalyst (Boocock, et al., 1996a). The biodiesel industry currently uses sodium methoxide, since methoxide cannot form water upon reaction with alcohol (Zhou and Boocock, 2006a). Methanol is the commonly used alcohol in production of biodiesel. Other alcohols may also be used, such as ethanol, propanol, iso- propanol and butanol (Freedman et al. 1984, 1986; Schwab et al. 1987, Ali and Hanna, 1994). Cetane number (CN) is one of the primary indicators of diesel fuel quality. It is related to ignition delay time a fuel experiences once it has been injected into a diesel combustion chamber. Generally, shorter ignition delay time, results in higher $\mathrm{CN}$ and vice versa. Hexadecane which gives the cetane scale its name is high quality reference standard with short ignition delay time and arbitrarily assigned $\mathrm{CN}$ of 100 . Also $2,2,4,4,6,8,8$ heptamethylnonane is the low quality reference standard with long ignition delay time and albitrarily assigned CN of 15 (Knothe et al, 1997).

Although a number of studies on the production of biodiesel from vegetable oils have been carried out, there is very little on the use of waste frying oil as feedstock. Therefore the objective of this study is to employ waste frying oil in the production of biodiesel via esterification and transesterification. Its fuel properties will also be determined and compared with the set ASTM standards.

\section{MATERIALS AND METHODS}

Sample Collection and Preparation: Waste frying oil was obtained from a commercial food store in Sapele, Delta State. The oil was screened to remove the heavy particle prior to transesterification.

Transesterification Method: Esterification: The oil had an FFA content of $14.8 \%$, and therefore, there is need for reduction below $0.5 \%$, otherwise there will be high saponification (Van Gerpen et al., 2005). This reduction was achieved via esterification of the oil with methanol and using tetraoxosulphate (VI) acid as the catalyst. 50 $\mathrm{g}$ of the oil was measured and place into three neck round bottom flask and placed in a water bath and heated to a temperature of $60^{\circ} \mathrm{C} .5 \% \mathrm{w} / \mathrm{w}$ acid was mixed with $20 \% \mathrm{w} / \mathrm{w}$ methanol and also heated to a temperature of $60^{\circ} \mathrm{C}$ and mixed with the oil. A suspended mechanical stirrer was inserted into the oil via one of the necks, the flask was equipped with a reflux condenser and a thermometer was dipped into the mixture via the remaining neck of the flask. The mechanical stirrer was set at $700 \mathrm{rpm}$ and timing was started at this point. A picking pipette was used to withdraw samples at one hour intervals $(1,2,3,4$ and $5 \mathrm{~h}$ ) and was titrated against $0.1 \mathrm{~N}$ solution of $\mathrm{KOH}$ to determine the \%FFA.

Transesterification using base as catalyst. The alkoxides used in the reaction were prepared by dissolving 0.1 weight $\%$ sodium hydroxide in methanol in a conical flask and left overnight. Into the alkoxides contained in the conical flask were added WFO (200 $\mathrm{ml}$ ) gradually, under a reflux condenser and a stirring device, while heating at $60 \mathrm{oC}$ for $15 \mathrm{mins}$. The two layer mixture formed thereof was extracted with nheptane to obtain the methyl ester and glycerol layer run off. The methyl ester/n-heptane mixture left was washed until neutral $\mathrm{pH}$ with water, after which the solvent was removed to obtain a clear, golden-yellow, less viscous methyl ester (Feuge and Grose, 1949).

Characterization of the Sample The physico-chemical properties of the Waste frying oil (WFO) and the methyl esters were determined using ASTM standard methods (ASTM D 1639-90, 1994; ASTM D 1541-60, $.1979 \mathrm{a}$; ASTM D 1541-60, .1979b).

Biodiesel properties of the WFO, methyl esters were determined using ASTM standard methods (ASTM, 2003)

\section{RESULTS AND DISCUSSION}

The physical and chemical properties of the waste frying oil (WFO) are presented in Table 1 and they were found to be in accordance with literature values (Alptekin and Canakci, 2008). The properties include; Saponification value $(183.37 \mathrm{mg} \mathrm{KOH} / \mathrm{g}$ oil), Iodine value $(109.06 \mathrm{gI} / 100 \mathrm{~g})$ acid value $(14.40 \mathrm{mg} \mathrm{KOH} / \mathrm{g})$, percent free fatty acid $(6.70 \%)$, viscosity $(12.10 \mathrm{cst})$ and specific gravity (0.96) respectively. The colour of the WFO is dark brown this was ascribe to the continue frying of the oil. The \% FFA of the waste frying oil was $14.4 \%$ which was not within the ASTM specified limit of $\leq 0.5 \%$ for biodiesel production. However, Dorado, et al., 2002 confirmed that to complete alkali catalyzed reaction, a free fatty acid (FFA) value lower than 3\% is needed. WFO was further esterified to achieve the \% FFA need for transesterification. The result obtained hitherto after esterification is as shown in Table 1. The specific gravity, acid value $(\mathrm{mgKOH} / \mathrm{g}, \% \mathrm{FFA}$, iodine value $(\mathrm{g} \mathrm{I} 2 / 100 \mathrm{~g})$ and saponification value $(\mathrm{mgKOH} / \mathrm{g})$ are $0.96,14.40,6.71,109.06$ and 183.3 respectively 
Table 1: Physico-chemical properties of esterified waste Frying Oil (WFO)

\begin{tabular}{ll}
\hline Property & WFO \\
Colour & Dark Brown \\
Specific gravity & 0.96 \\
Acid value $(\mathrm{mg} \mathrm{KOH} / \mathrm{g})$ & 14.40 \\
FFA $(\%)$ & 6.71 \\
Iodine value ( I2 /100g) & 109.06 \\
Saponification value $(\mathrm{mg} \mathrm{KOH} / \mathrm{g})$ & 183.37 \\
Viscosity (cst) at 400C & 12.10 \\
Cetane Number & 51.52 \\
\hline
\end{tabular}

Results of Esterification: The results obtained from the esterification process at various reaction time of the WFO ranging from 0 to $250 \mathrm{~min}$. as shown in Figure 1. The acid value $(\mathrm{mg} \mathrm{KOH} / \mathrm{g})$ of the WFO is not within the specified ASTM standard for transesterification process. This caused the need to reduce the acid value content of the oil through esterification. It was observed from Figure 1 that at 0 minute, the acid value content of the oil was $11.62(\mathrm{mg} \mathrm{KOH} / \mathrm{g})$. This value decreased to $9.99(\mathrm{mg} \mathrm{KOH} / \mathrm{g})$ after the first $60 \mathrm{~min}$ of the reaction, further dropped to $1.03(\mathrm{mg} \mathrm{KOH} / \mathrm{g})$ at $240 \mathrm{~min}$ with FFA content of $0.47 \%$ before the reaction was terminated; this was within the specified limit of $\leq 0.5 \%$ for transesterification process (Singh et al 2009).

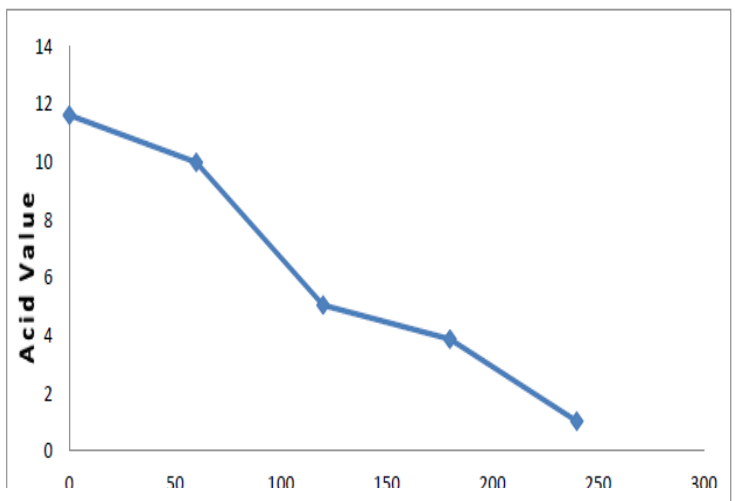

Fig 2: Effect of reaction time on the yield of FO methvl ester

Cetane number is an indicator of the ignition characteristics of fuel in diesel engines. The cetane number is an engine based test and measures how easily ignition occurs, and the smoothness of combustion. Generally, shorter ignition delay number and vice versa. The oil samples: WFO, EWFO and methyl ester produced thereof had a $\mathrm{CN}$ of 51.52 , 52.20 and 53.39 respectively.

Oils have greater potentials of polymerizing due to high iodine value. Iodine value is determined for oil suitability for transesterification process as the unsaturation restricts the biodiesel from solidification (Azam et al., 2005).
Table 2: Fuel properties of EWFO and WFO methyl esters

\begin{tabular}{lll} 
Time (minutes) Property & EWFO & WFO Methyl ester \\
\hline Colour & Dark brown & Golden yellow \\
Specific Gravity & 0.89 & 0.83 \\
Acid Value $(\mathrm{mg} \mathrm{KOH} / \mathrm{g})$ & 0.3 & 0.10 \\
Viscosity $(\mathrm{cst})$ at $30^{\circ} \mathrm{C}$ & 9.72 & 4.83 \\
Fuel Potential MJ/Kg & 36.34 & 42.44 \\
Flash Point ${ }^{\circ} \mathrm{C}$ & 239 & 233 \\
Fire Point ${ }^{\circ} \mathrm{C}$ & 269 & 276 \\
Cetane Number & 52.20 & 53.39 \\
Iodine value $(\mathrm{g} \mathrm{I} 2 / 100 \mathrm{~g})$ & 106.33 & 101.78 \\
Saponification value $(\mathrm{mg} \mathrm{KOH} / \mathrm{g})$ & 183.06 & 181.99 \\
\hline
\end{tabular}

Effect of Variation in Time: Reaction time is a key parameter for methyl ester production. The reaction was varied at 20, 30, 40, 5060 respectively. The highest optimum yield was $97 \%$ at $40 \mathrm{~min}$ as shown in Figure 1. The reaction time was in the order of $40>50>60>30>20 \mathrm{~min}$.

Effect of reaction temperature: Figure 3, shows the graph or reaction temperature against yield of biodiesel produced. As the reaction temperature increased progressively, the methyl ester reaches its optimum yield of $97 \%$ at $50^{\circ} \mathrm{C}$ and decreased gradually. This high yield obtained during the biodiesel production could be as a result of the boiling point of the alcohol used which was higher than the temperature for optimization. Demirbas (2009) reported $60^{\circ} \mathrm{C}$ for conventional transesterification which was in abeyance with the result obtained in Figure 2. 
Effect of methanol-to-oil ratio : Figure 4 shows the effect of oil-to-methanol ratio on the methyl ester yield of the WFO. It can clearly be noticed that when methanol to-oil-ratio is increased the yield of methyl ester increased and reached a maximum at 1:6.

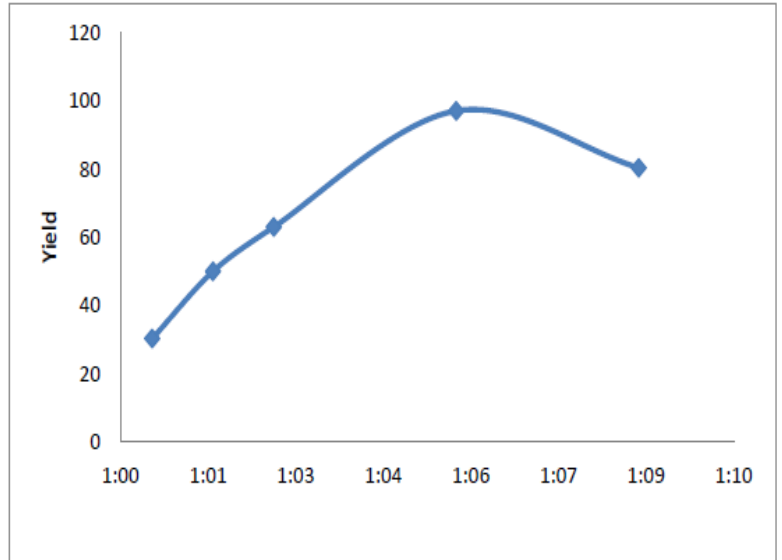

Fig 4: Effect of methanol/oil mole-ratio on the biodiesel yield
Increasing the oil-to-alcohol ratio beyond the optimum did not increase the yield. Further increase in the ratio resulted into decrease in the yield. Therefore, the optimum methanol-to-oil ratio was chosen as 1:6.

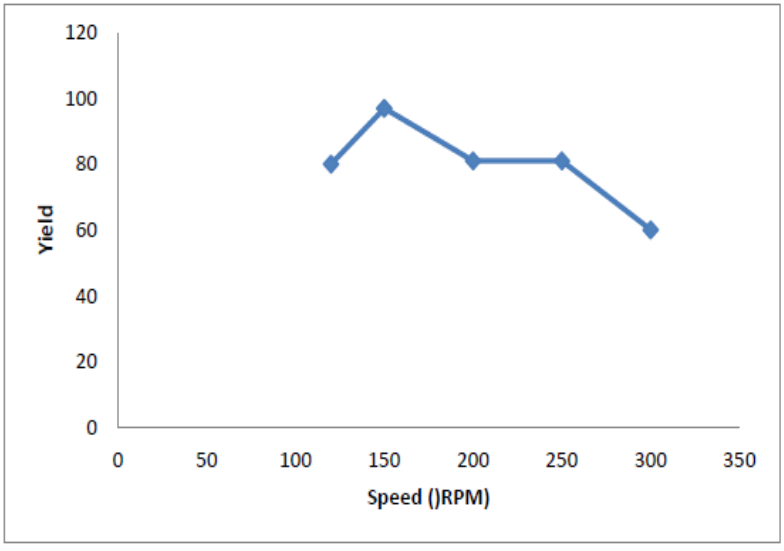

Fig 5: Effect of stirring speed on the yield of biodiesel produced

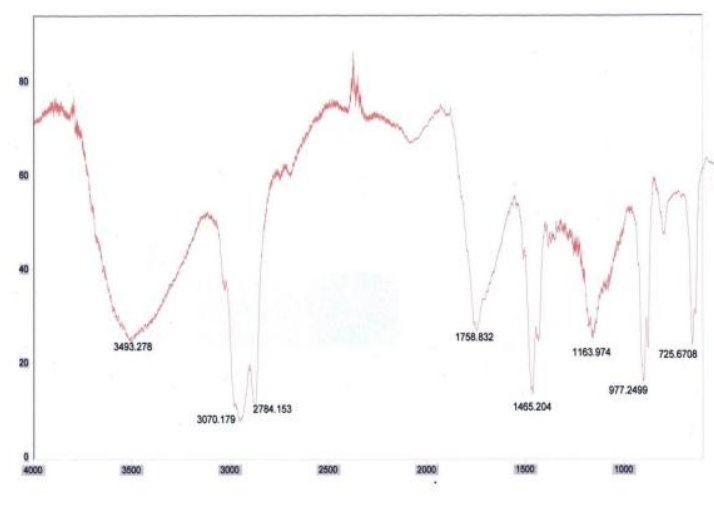

Fig 6: IR spectra of waste frying oil: Figure 6 shows the IR results for waste frying oil. The results for the different wavelength of adsorption is as shown 3493.273, 3070.179. 2784.153, 1758.832, 1465.204 and $1163.973 \mathrm{~cm}^{-1}$ for $\mathrm{OH}$ of carboxylic acid, Vinyl, $\mathrm{CH}_{2}=\mathrm{CH}_{2}, \mathrm{C}-\mathrm{H}$ of an aldehyde, $\mathrm{C}=\mathrm{O}$ of ester, $\mathrm{C}-\mathrm{H}$ of methylene and $\mathrm{C}-\mathrm{O}$ of esters respectively. This results obtained is an indication of the sample as an oil 


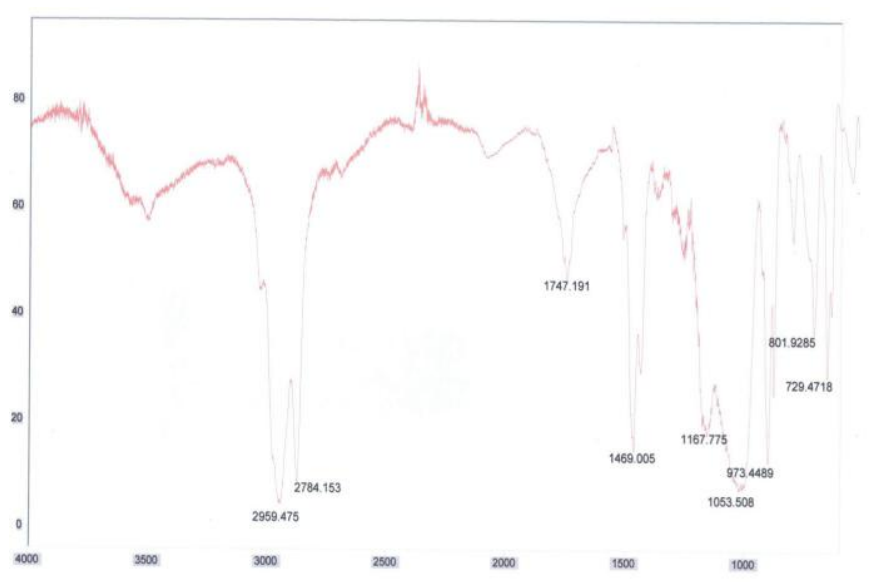

Fig7: IR spectra for Biodiesel from Waste frying oil

Fig 7 shows the IR results for biodiesel obtained by transesterification of the waste frying oil. The results for the different wavelength of adsorption is as shown; 2959.45, 2784.153, 1747.191, 1469.005 and 1167.775 respectively for $\mathrm{C}-\mathrm{H}$ of methyl, $\mathrm{C}-\mathrm{H}$ of an

Conclusion: Fuel performance index was carried out for waste frying oil (WFO), esterified form (EWFO) and methyl ester produced thereof. This was an attempt to convert waste into renewable energy source.

The result showed that esterification was effective in reducing certain parameters like acid value, percentage FFA etc to a value within ASTM limit for transesterification. Waste frying oil (WFO), esterified waste frying oil (EWFO) and methyl ester showed number of 51.52, 52, 52.20 and 53.39 respectively.

The production of methyl ester had highest optimum yield of $97 \%$ at 40 minutes, temperature of $50 \mathrm{oC}$ and decreased gradually at higher temperature. Methanol/oil ratio of 1:6 gives the optimum yield. The IR spectrum of the biodiesel reveals the replacement of heavier alkyl groups present in the WFO by the methyl from the alcohol (methanol).

\section{REFERENCES}

Ali, Y., Hanna, M. A.,(1994). Alternative Diesel fuel from Vegetable Oil. Bioresource Technologies.50:163.

Alpetekin E., Canakci, M. (2008). Determination of the density and viscosity of biodiesel -diesel blends. Journal of renewable energy. 33: (12):2623-2630. aldehyde, $\mathrm{C}=\mathrm{O}$ of esters, $\mathrm{C}-\mathrm{H}$ of methylene and $\mathrm{C}-\mathrm{O}$ of ester. This result is an indication that there was a replacement of the alkyl group present in the WFO by the methyl from the alcohol (methanol) used.

ASTM Standard specification for fuel oils. In: Annual Book of ASTM Standards, ASTM

International, West Conshohocken, Method D396-08b; 2008d.

ASTM Standard specification for diesel fuel oil, biodiesel blend (B6 to B20). In: Annual Book

of ASTM Standards, ASTM International, West Conshohocken, Method D7467-08a; 2008b.

Azam, M. M., Waris, A., Nahar, N.M. (2005). Prospects and potentials of fatty acid methyl esters of some non traditional seed oils for use as biodiesel in India. Science Direct :Biomass and Bioenergy. 28:293-302

Boocock D. G. B., Konar S. K., Mao V., Sidi H.(1996a) Fast one-phase oil rich processes for the preparation of vegetable oil methyl esters. Biomass. Bioenerg. 11: 43-50.

Demirbas A.(2006) Biodiesel production via noncatalytic SCF method and biodiesel fuel characteristics. Energ. Convers. Manage. 47: 2271-2282.

Demirbas A. (2009) Progress and recent trends in biodiesel fuels. Elsevier J. Energy Conversion Manage., 50:14-34.

Feuge, R.O., Grose, T. (1949). Modification of vegetable oils. VII. Alkali catalyzed 
interesterification of peanut oil with ethanol. J. Am. Oil Chem. Soc., 26: 97-102.

Freedman B., Pryde E. H.(1984) Mounts T. L. Variables affecting the yields of fatty esters from transesterified vegetable oils. J. Am. Oil Chem. Soc. 61: 1638-1643.

Freedman B., Butterfield R. O., Pryde E. H. (1986). Transesterification kinetics of soybean oil. J. Am. Oil Chem. Soc. 63: 1375-1380.

Gunstone F. D., Harwood J. L.(2007) Occurrence and characterization of oils and fats. In: Gunstone F. D.; Harwood J. L.; Dijkstra A. J. (eds) The lipid handbook. 3rd ed. CRC, Boca Raton, pp 37-142.

Knothe G., Bagby M. O., Ryan T. A. (1997) Cetane numbers of fatty compounds: influence of compound structure and of various potential cetane improvers. SAE Tech. Pap. Ser. 971681: $127-132$.

Moser, Bryan R. (2009). Biodiesel production, properties and feedstocks. In vitro cell. Dev. Boil-plant 45:229-266. Schwab A. W., Bagby M. O., Freedman B. (1987) Preparation and properties of diesel fuels from vegetable oils. Fuel 66: 1372-1378.
Singh, R., Kaushik, S., Wang, Y., Xiang, Y. (2009) Autophagy regulates lipid metabolism. Nature: International weekly journal of Science. 458: 1131-1135.

United States Department of Agriculture, Foreign Agricultural Service, (USDA) Office of Global Analysis(2008). Oilseeds: World Markets and Trade, Circular Series FOP 12-08, Table 03, pg. 5.

Van Gerpen, Gerhard K and Jurgen K (2005). Handbook of Biodiesel, AOCS Press Champaign Illinois.

Zhou W.; Boocock D. B. G. (2006a)Phase behavior of the base-catalyzed ransesterification of soybean oil. J. Am. Oil Chem. Soc. 83: 10411045. 